\title{
Biomedical and medical education within a digital society
}

\author{
Josef Berger
}

Institute of Medical Engineering and Biophysics, Faculty of Health and Social Care, South Bohemian University in České Budějovice, Czech Republic

\begin{abstract}
Summary
Digital computers, which elevate the capacity of both individuals and human society, spread their possibilities widely in education. Software supports the teaching of physiology, anatomy, radiology, nursing, laboratory sciences and other fields of medicine. Existing learning programmes were assigned to drill and examined. The extension of the capacity of software graphics and penetration into research and practice makes it possible to use original documents and images and, therefore, to construct virtual reality which elevates effectiveness in facility training and the teaching of a creative approach among students. The Internet has been a major communication medium since the mid nineties. It brings greater democracy into the education process and makes it easier to admit data necessary in distance learning. Important databases (Web of Science, Medline etc.) have become part of ambitious university learning programmes; these databases are also available on the Internet. Despite technological progress in digital technology, many educational programmes contain only texts although web sites can be updated more frequently than printed textbooks. It is advantageous when a teacher helps and stimulates searching for excellent sites on the internet.
\end{abstract}

Keywords: education - biomedicine - Internet - student's activity

\section{INTRODUCTION}

Digital computers have increased the capabilities of individuals, institutions, and human society by providing an increasingly powerful means for manipulating numbers and symbols in an algorithmic manner (cf. Kampfber 2002). Let us put the following three questions: (i) What is the recent role of computers in the education process within the framework of historical consequences? (ii) Which problems arise from the computer support of teaching? (iii) Can we expect a role for computers in future learning?

Dissemination of information and digital technologies do advance human intellectual capacity and we can, therefore, observe a significant increase in the impact of computer support for teaching and learning during the past thirty years. Interactive digital technologies seem to be an important factor in this trend as they constitute an appropriate environment which includes both texts and images, that are components for virtual reality. Virtual reality is recognised for its enormous educational potential in human anatomy, biochemistry and molecular biology (Hoffman and Vu 1997).

\section{HISTORICAL HEADSTONES OF INTERNET EDUCATION}

The ancient computers used for education had possibilities to communicate only using characters and semigraphic symbols. Ancient software was used for drill and testing. When personal computers became the standard several areas of medicine tested programme packages for self-assessment and examinations (cf. Piemme 1988, Kossekova et al. 1989, Wu et al. 1990, Henry 1990, South and Nolan 1993, Berger 1993). Scientific electronic databases of published papers were accepted as one teaching tool (e.g. Proud et al. 1989).

The computer and the projector can be used by a teacher during lectures (Thomson 1998) and students seek active learning experiences that can rapidly impart relevant information in the most convenient way 
(Dwyer et al. 1997). Using a friendly interface based on images from pixels is linked to the progress of digital technology (Awbrey 1996, Robb 1999, Druckmuller 2001) and its application makes it possible to design-interactive software supporting the creative work of students. Current educational software has a frequently multimedia nature which supports both abstract and practical teaching through computer simulations (Graham a Martin 1998, Delpech 2000, Scherly et al. 2000).

Computer support for the educational process accelerated from the middle of the nineties when the Internet became a usual information tool for students, teachers, researchers and publishers (Harris et al. 2001). Using the Internet is the logical step following previous experience with teaching software for a single computer as the Internet is a major communication medium. There are sites which offer a large reservoir of information for both teachers and students (cf. Peat and Fernandez 2000).

Intranet networks and the Internet enable faster communication between a teacher and students; simple tutorials can be made using e-mail. Internet expansion following information and digital technology has made possible the development of educational software for both regular and distance education. The Internet has reduced the difficulties in both mentioned form of education (Lagowski 1999, Parry 2001, Sigulem 2001, Yip et al. 2001).

The internet has permitted the global distribution of medical (Harris et al. 2001) and biomedical education and thus, the Internet within a framework of its price accessibility offers democracy for education and enlargement of learning sources because it permits free (or cheap) access to learning materials and scientific sources. It seems a side-effect of the Internet will be changes in the content and format of many paperprinted journals and books.

Ethical and economical problems in the use of laboratory animals, volunteers and patients for demonstration or practical drill generate a pressure to use alternative models including computer simulations (Hoffman and $\mathrm{Vu}$ 1997). This influence supports electronic education indirectly, but strongly (see Price1999, Marks 2001).

\section{IMPACT OF THE INTERNET ON EDUCATION}

Education and training in traditional information literacy, for librarians as well as for teachers and students, are no more adequate for current demands, even if well established and not over-sophisticated (Špála and Choc 1996). There are several areas where computers have supported biomedical and medical research, practice and education for many years:

Web sites, which are free of charge and oriented to support teaching and learning in entire biomedicine, are still not common while surfing on the Internet, we can find educational sites oriented towards one scientific branch, for example biochemistry (http://schmidel.com/wojcik.cfm, http://www.usm.maine.edu/ rhodes/Biochem, http://www-su.indstate.edu/thcme/mwking/home.html etc.), immunology (http://www.assim.refer.org, http://allergy.mcg.edu/students/stObj.html, http://mbisg4.sbc.man.ac.uk/immunology.html).

Haematology education through the Internet can exploit digital imaging microscopy, which is also used for documentation or can play an important role in computer aided cytological diagnosis (Alexandratou et al. 1999; http://archive.uwcm.ac.uk/uwcm/publish/curricula/me dical/haematology - The University of Wales haematology,

http://www.medicalstudents.co.uk/thaematology.htm an educational site for UK medical students, http://medocs.ucdavis.edu/IMD/420A/course.htm The University of California haematology course resources, http://w3.ouhsc.edu/hemaonco/hempath.htm - virtual haemopathology, (Fig. 1)

http://www.bggp.co.uk/presentations/haematology/ind ex.htm - haematology for fun,

http://www.infobiogen.fr/services/chromcancer/IntroIt ems/hempat_e.html - atlas of genetics and cytogenetics in oncology and haematology etc.).

Let us explain how a complex programme for education can be developed using the example from haematology, i.e. sites of the Department of Pathology and Laboratory Medicine at Health Science Centre at Houston which are made by Nguen and co-workers (http://dpalm.med.uth.tmc.edu/faculty/bios/nguyen/nguy en.html). They developed the computer's decisionsupport systems for differential diagnosis of coagulation disorders (Nguyen et al. 2000), laboratory diagnosis of haemoglobin disorders (Nguyen et al. 1996), and differential diagnosis of haematologic neoplasms using immunophenotyping data obtained with flow cytometry (Nguyen et al. 2001). Web-based courses for haematology teaching have been developed by this department following their experience with the expert database systems mentioned above. 


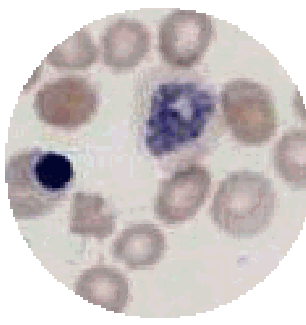

Best viewed with

Netscape 2.02 or

higher.

$$
\begin{gathered}
\text { For less graphically- } \\
\text { orientedbrowsers, } \\
\text { click this } \\
\text { streamlinedversion. } \\
\text { For browsers not } \\
\text { supportingClient-side Image } \\
\text { Maps, click from the choices } \\
\text { below: }
\end{gathered}
$$

\section{ViewCurrent Case}

SeeOld Records

AddYour Case

SendYour Comments

Creditsand Authors

\author{
Jumpto Links \\ Beyond
}

Disclaimer

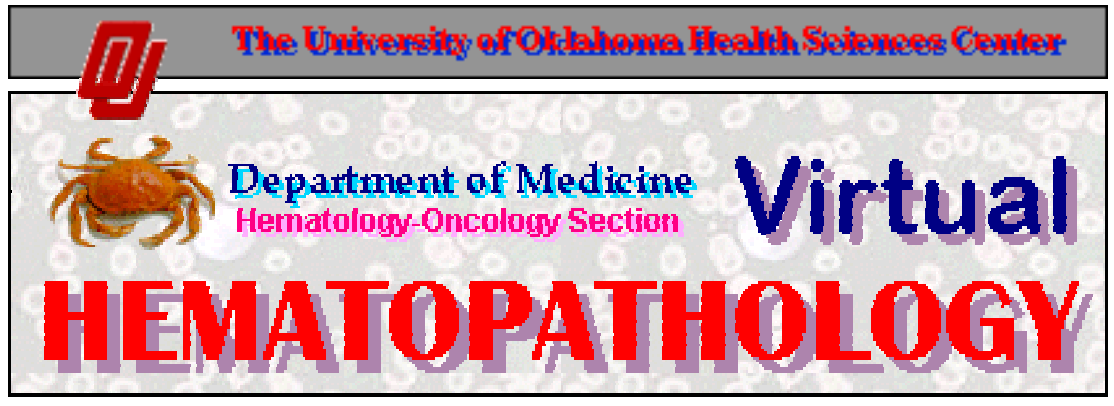

\author{
Diagnose real cases in the VirtualWorld. Each month, \\ a short case summary including the history, \\ pertinent physical examination, laboratory data \\ and microscopic slides is presented. \\ Your task is to make the diagnosis.
} The actual diagnosis will be published the following month.

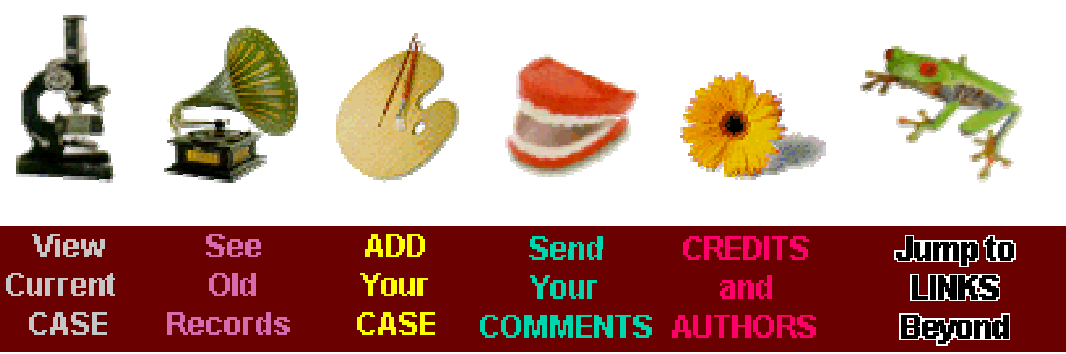

Fig. 1. An example of the good educational support on the Internet: the website of the University of Oklahoma for haematology teaching

Courses in medical anatomy, neurobiology, ethics, reproductive medicine, radiology and histology for medical students are relatively frequent on the Internet (http://www.ombregt.be, http://thalamus.wustl.edu, http://www.meddean.luc.edu/lumen/MedEd/medicine/pu lmonar/pulmon.htm,

http://medocs.ucdavis.edu/IMD/420A/course.htm, http://rad.usuhs.mil,

http://matweb.hcuge.ch/endo/Lectures 8th PGC/8th po stgraduate_course_files.htm,

http://matweb.hcuge.ch/endo/Lectures_9th_PGC/index.h tm, http://chorus.rad.mcw.edu). These programmes use digitizing equipment to receive presented images. The lower graphics resolution of images exhibited on the Internet could be a defect depending on the recent level of Internet technology but this is the same problem as for cytological haematology images. On the other hand, educational photos can be adapted to accentuate important features of the object and such images need not contain high resolution. A simple course in human anatomy could be useful as a support for biomedical studies. 
Navod/User manual Resitele/Project partners O projektu/About project Statistiky vyuziti/Usage Reports

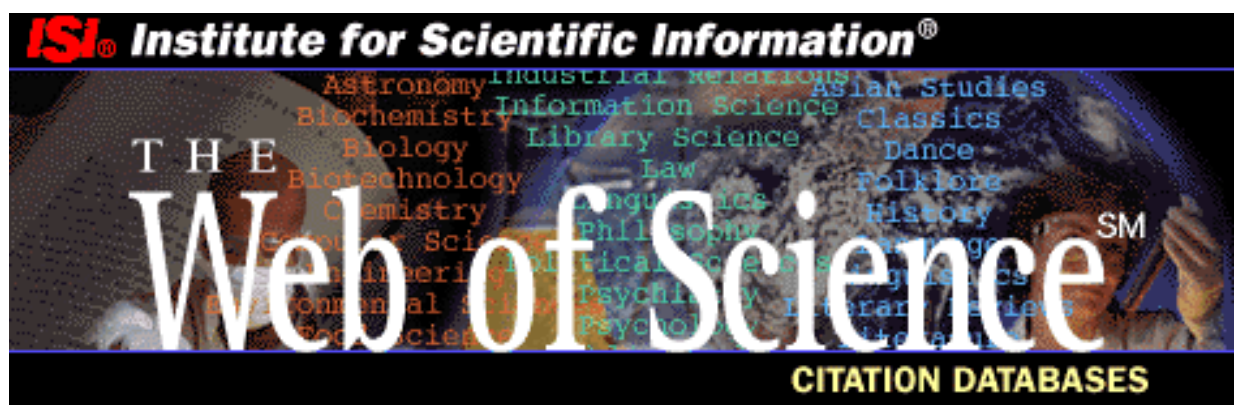

Full Search Use the Full Search to conduct searches on a topic or by author and also to find articles which cite these works or which use related references.

Easy Search Use the Easy Search to find articles on a specified topic, person or place of interest.

\section{Notices}

The Notices file was last updated 3/30/2001

Copyright (C) 2002 Institute for Scientific Information

Fig. 2. Opening site of The Web of Science where there is a large database of published papers (http://wos.cesnet.cz; paid access); access for Czech participants is in the Czech language

Very useful for both medical and biomedical teaching are programmes supporting physiology education since computer-based programmes can effectively train off-side students and practitioners in an interpretation (cf. Kittnar et al. 1991, Wiemer 1998, Lum and Gross 1999, Lo 2000, http://www.hoflink.com/ house/humphy.html),

Computers have not seemed to be very useful in some other areas of medical and social care even when they are pivotal, e.g. nursing. Currently nursing information includes nursing dictionaries, using telecommunication to support care delivery, enhancing decision through research agendas and transforming education (Delaney 2001, Veenema 2001). Internet technology provides an innovative way to design and develop a cost effective, flexible system of Continuing Nursing Education to help staff learn (Mak et al. 2001). Graduate-level health courses at nursing faculties can incorporate problems concerning differential diagnosis and focus on abnormal findings (Kelley and Kopac 2001). Internet technology, through its interactivity, can support distance learning of nurses and thus eliminate trends towards a shortage of registered nurses in the future (O'Brien and Renner 2000). An example of a free virtual seminar offering Internet training for nurses, psychologists, social workers, psychiatrists and counselors is available at http://www.virtualcs.com/, paid courses at http://www.ce-web.com etc.

Databases of published papers are a very important educational resource e.g. Medline, Current Contents, SCI; (see Fig. 2 and 3). The student can learn to find appropriate information which is reviewed regularly thus eliminating imperfect data. Other valid sources are web sites edited by erudite staff. Such sites can include a discussion forum (see web sites edited for haematology by the Haematology Department at Hammersmith Hospital, London, UK: http://www.haem.net). 


\section{untreb staris National Library of Medicine}

Site Index Search Our Web Site

\section{HeALTH INFORMATION \\ MEDLINE/PubMed, MEDLINEplus, NLM Gateway}

LIBRARY SERVICES

Catalog, Databases, Historical Materials, MeSH, Publications, Training, Grants, Network of Libraries

\section{RESEARCH PROGRAMS \\ Computational Molecular Biology, Medical Informatics, Visible Human Project, UMLS}

\section{NEW \& NOTEWORTHY}

Announcements, Exhibits, New on this Site, Hot Topics

\section{General INFORMATION}

Visiting the Library, FAQs, Staff, Jobs, Contacts

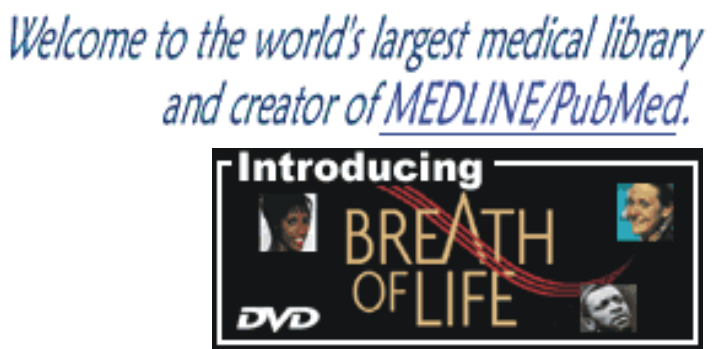

For the Public MEDLINEplus Health Information

ClinicalTrials.gov provides information for patients about clinical research studies

U.S. National Library of Medicine, 8600 Rockville Pike, Bethesda, MD 20894

National Institutes of Health, Department of Health \& Human Services

Copyright and Privacy Policy, Freedom of Information Act, Accessibility

\section{FIRSTGOV}

Fig. 3. Medline access at http://www.nlm.nih.gov. Here is the database of medical and biomedical published papers

\section{CURRENT PROBLEMS}

The Internet provides an exciting learning opportunity. The main challenge in the education of undergraduate students is their capacity to evaluate the quality of a website. We think, in agreement with Peat and Fernandez (2000), that the main problem of current internet courses is their non-interactive 'textbook' mode although we are sure that texts on the internet can be easily updated.

Contrary to Kaspar (2002) in Santa Cruz (USA), we do not have problems with the student's facility in using the Internet in České Budějovice (Czech Republic). Our experience is that the students learn to use and estimate the internet source, and this is in concordance with the same authors. This question does not depend on internet technology but rather on knowledge and experience of the students. A student may be alert when he sees a site without an author or an author without apparent professional background because such sites can contain mechanically transcribed old textbooks with obsolete data. The teacher's assistance in selecting appropriate sites is a necessary factor in this situation.

\section{PERSPECTIVES}

Visualization in biomedical computing makes it possible to extend medicine and biomedicine across a vast range, from molecules to body parts and to include functional aspects of these systems, such as biophysical, biomechanical and physiological properties, accurate anatomy and enhanced diagnosis (Robb 1999). Therefore, virtual reality on-line can be useful for both clinical procedures and education.

At the simple level, virtual microscope handling of digital slides makes possible data manipulation at a level which is not reached with conventional microscopy; moreover, as slide digitization is a method of archiving salient cytological and histological 
features (Leong and McGee 2001), the production of special-teaching slides falls off. Virtual slides can be made by scanning films or, at present the common way, using CCD cameras (Berger 2000, 2001, 2002); several video technologies allow easy digitization, too (Jog and Grantier 2001).

It seems that the medical and biomedical applications of virtual reality (Camp et al. 1998) in teaching and learning as well as research and diagnostic purposes.will serve as an important part of the educational process in the $21^{\text {st }}$ century The construction of an interface between digital computing, and biological computing, with its adaptability and efficiency (Kampfner 2002), could lead in the future to a new expansion of digital technology into human society including teaching and learning.

\section{ACKNOWLEDGEMENT}

This study has been financially supported by Ministry of Education, grant no.1259/02.

\section{REFERENCES}

Alexandratou E., D. Yova, D.V. Cokkinos: Morphometric characteristics of red blood cells as diagnostic factors for coronary aretry disease. Clin. Hemorheol. Microcirc. 21: 383 - 388, 1999.

Awbrey S.M.: Successfully integrating new technologies into the higher education curriculum. Educ. Technol. Rev. 5, 1996

Berger J.: Informatika v klinické praxi. Grada/Avicenum, Praha1993.

Berger J.: Microscopic digital image processing. In J. Berger (ed.): Cells. Kopp Publ., České Budějovice 2000, p. 179.

Berger J.: Současné trendy digitalizace $\mathrm{v}$ hematologii. In F. Weyda (ed): Digitální zobrazování v biologii a v medicíně. Entomologický ústav AV ČR, České Budějovice 2001, p. 29 - 30.

Berger J.: Education in laboratory haematology and internet. Haematol. J. 3, Suppl. 1: 85 - 86, 2002.

Camp J.J., B.M. Cameron, D. Blezek, R.A. Robb: Virtual reality in medicine and biology. Fut. Gen. Comp. Syst. 14: $91-108,1998$.

Delaney C.: Health informatics and oncology nursing. Semin. Oncol. Nurs 17: 2 - 6, 2001.

Delpech R.: Investigating the phenomenon of programmmed cell death in maize seeds. J. Biol. Educ. 35: $41-44$, 2000.

Druckmuller M.: Adaptive image processing in biology. In J. Berger (ed): Cells III, Kopp Publ., České Budějovice 2001 , p. $71-79$.

Dwyer TM, Fleming J, Randall JE, Coleman TG: Teaching physiology and the World Wide Web: Electrochemistry and electrophysiology on the Internet. Adv. Physiol. Educ. 18: S2-13, 1997.
Graham J and R. Martin: Teachers, schools and the new technologies: a disacussion paper. Austr. Educ. Comp. 13: (No 2): 6 - 12, 1998.

Harris J.M., S.J.Salasche, R. B. Harris: The internet and the globalisation of medical education. Brit. Med. J. 323: 1106, 2001.

Henry J. B.: Computers in medical education: Information and knowledge management, understanding, and learning. Hum. Pathol. 21: 998 - 1002, 1990.

Hoffman H. and D. Vu: Virtual reality: Teaching tool of the twenty-first century. Acad. Med 72: 1076 - 1081, 1997.

Jog M.S., L. Grantier: Methods for digital video recording, storage, and communication of movement disorders. Mov. Disord. 16: 1196 - 1200, 2001.

Kampfner R. R.: Digital and biological computing in organizations. BioSystems 64: 179 - 188, 2002.

Kaspar RL: Integrating Internet assignments into a biochemistry/molecular biology laboratory course. Biochem. Mol. Biol. Educ. 30: 36-39, 2002.

Kelley FJ, Kopac CA: Advanced health assessment in nurse practitioner programs. J. Profess. Nurs, 17: $218-225$, 2001.

Kittnar O., M. Vávrová, S. Trojan: Computer-aided physiology (teaching, learning and research). Physiol. Res. 40: 549 - 553, 1991.

Kossekova G.P., N. C. Vrabchev, L. M. Sirakov: A program package for self-assessment and examination in biochemistry. Comput. Biol. Med. 19: 173 - 179, 1989.

Lagowski J.J.: The role of distance in chemical education. Pure Appl. Chem. 71: 845 - 850, 1999.

Leong F. J., J. Q. McGee: Automated complete slide digitization: a medium for simultaneous viewing by multiple pathologists. J. Pathol. 195: 508 - 514, 2001.

Lo C.: Integrating nutrition as a theme throughout the medical school curriculum. Amer. J. Clin. Nutr. 72: 882S-889S, 2000.

Lum E. H., T. J. Gross: Telemedical education: Teaching spirometry on the Internet. Adv. Physiol. Educ. 21: S55 - S61, 1999.

Mak HY, Mallard AP, Kwok JCK: Designing a hospital intranet nurse learning system for improving continuing nursing education. Innov. Educ. Train. Intern. 38: 397 405, 2001.

Marks Jr S.C.: Recovering the significance of 3-dimensional in medical education and clinical practice. Clin. Anat. 14: 90 - 91, 2001.

O'Brien B.S., Renner A.: Nurses on-line: Career mobility for registered nurses. J. Profess. Nurs. 16: 13 - 20, 2000.

Nguyen A.N.D., Hartwell E., Milam J.: A rule-based expert system for laboratory diagnosis of hemoglobin disorders. Arch. Pathol. Lab. Med. 120: 817-827, 1996.

Nguyen A.N.D., Uthman M.O., Johnson K.A.: A Web-Based Teaching Program for laboratory diagnosis of coagulation disorders. Arch. Pathol. Lab. Med. 124: 588$593,2000$.

Nguyen A., Wu S., Jalali M., Uthman M., Johnson K., Banez E.: A web-based database for diagnosis of haematologic neoplasms using immunophenotyping by flow cytometry. Med. Inform. Internet Med. 26: $309-$ 323, 2001.

Parry D.: Using the Internet to teach health informatics: a case study. J. Med. Internet. Res. 3: E26, 2001. 
Peat N., A. Fernandez: The role of information technology in biology education: an Australian perspective. J. Biol. Educ. 34: 69 - 73, 2000.

Piemme T. E.: Computer-assisted learning and evaluation in medicine. J. Amer. Med. Assoc. 260: 367 - 372, 1988.

Price R.R.: The AAPM/RSNA physics tutorial for residents - MR imaging safety considerations. Radiographics 19: $1641-1651,1999$.

Proud V.K., F. J. Schmidt, E. D. Johnson, J. A. Mitchell: Teaching human genetics in biochemistry by computer literature searching. Amer. J. Hum. Genet. 44: 597 604, 1989.

Robb R. A.: Visualization in biomedical computing. Parall. Comp. 25: 2067 - 2110, 1999.

Scherly D., L. Roux, P. Dillenbourg: Evaluation of hypertext in an activity learning environment. J. Comp. Assist. Learn. 16: 125 - 136, 2000.

Sigulem DM, Morais TB, Cuppari L, Franceschini SC, Priore SE, Camargo KG, Gimenez R, Bernardo V, Sigulem D: A Web-based distance education course in nutrition in public health: case study. J. Med. Internet. Res. 3:E16, 2001; http://www.jmir.org/2001/2/e16/.
South M. and T. Nolan: Computer-assisted instruction in Australian medical schools. Med. J. Austr. 159: 175 176, 1993.

Špála MR, Choc F.: A new task for the information literacy training by the university libraries: electronic media and computer networking. Sb. Lek. 97: 445 - 448, 1996

Thomson M.: Multimedia anatomy and physiology lectures for nursing students. Comp. Nurs. 16: 101-108, 1998.

Veenema T.G.: An evidence-based curriculum to prepare students for global nursing practice. Nurs. Health Care Perspect. 22: 292 - 298, 2001.

Wiemer W.: It's a long way to multimedia: An account of 18 years of pursuing a new media project in physiology. Adv. Physiol. Educ. 20: S96-S105, 1998.

Wu A. H. B., M. LaRocco, S. J. Fath, F. A. Simon: Evaluation of computer case simulations for teaching clinical pathology to second-year medical students. Ann. Clin. Lab. Sci. 20: 154 - 160, 1990.

Yip H.K., R. J. Smales, F.C. Chu, P.R.Newsome, T.W. Chow: Computer-assisted learning (CAL) in undergraduate clinical dentistry: a review. SADJ 56: 476 $-480,2001$.

\section{Address:}

Josef Berger, Faculty of Health and Social Care South Bohemian University, Branišovská 31, 37005 České Budějovice, Czech Republic; berger@jcu.cz 